\title{
Implementation of Human Economic Rights in Transition States
}

Submitted 02/05/20, $1^{\text {st }}$ revision 30/05/20, $2^{\text {nd }}$ revision 26/07/20, accepted 15/08/20

\section{Olena H. Kozynets ${ }^{1}$, Alla G. Nitchenko ${ }^{2}$, Oleksandr M. Holovko ${ }^{3}$, Svitlana O. Shestakova ${ }^{4}$, Leonid L. Tarasenko ${ }^{5}$}

\section{Abstract:}

Purpose: To determine the level of implementation of human economic rights in countries in transition, to establish causal links between the level of economies of transition states and the implementation of human economic rights and to develop ways to improve conditions for their implementation.

Design/Methodology/Approach: To achieve the purpose specified, an elementary theoretical method, a method of comparison, analysis, generalization and analogy have been used.

Findings: The level of economic development of individual countries in transition (Ukraine, Latvia, the Czech Republic) in comparison with highly developed countries (Denmark, Japan, Iceland) has been presented. The reasons for the low level of ensuring the implementation of human economic rights in transition states have been clarified (shadow economy of enterprises, inadequate conditions for investors, insufficient level of economic development, leveling by human capital, job cuts, high level of corruption, lack of innovative technologies). The cause and effect link between the level of economic development, the unemployment rate, the attraction of human capital, the conditions of doing business, corruption and the implementation of economic rights have been proved.

Practical Implications: This study suggests ways of improving the conditions for the realization of economic human rights. These rights are developed to reform areas that are directly related to the improving process of the economies of transition countries.

Originality/Value: The study emphasizes that the level of realization of economic human rights in transition countries depends on the economic development of the country.

Keywords: Economic rights, transition period, state in transition (transition country), transformation of economy.

JEL Codes: D1, D11, D18, G1, G18.

Article Type: Research paper.

\footnotetext{
${ }^{1}$ Associate Professor, Chernihiv National University of Technology, Chernihiv, Ukraine, E-mail:elena_8067@ukr.net

${ }^{2}$ Associate Professor, Chernihiv National University of Technology, Chernihiv, Ukraine,

E-mail: nitalla2014@gmail.com

${ }^{3}$ Professor, V.N. Karazin Kharkiv National University, Kharkiv, Ukraine,

E-mail: golovkoan1967@ukr.net

${ }^{4}$ Associate Professor, Sumy National Agrarian University, Sumy, Ukraine,

E-mail: Sshestakoval@ukr.net

${ }^{5}$ Associate Professor, Ivan Franko National University of Lviv, Lviv, Ukraine,

E-mail: tarasenkoleo@gmail.com
} 


\section{Introduction}

Countries in transition have come a long way in transforming their economies from planned to market one. During this difficult period, each of the states has chosen its own path of development, which centers around reforming those areas that are directly related to the economy. The economic rights of citizens who have undergone transformation simultaneously with the economy of countries in transition are no exception.

It is the duty of the state to ensure the implementation of people's economic rights. The ability to satisfy economic rights by the state is characterized by the established minimum standard limit, which is reflected in the financial well-being of the population. The implementation of economic rights is the basis for ensuring other humans' rights therefore, a sufficient standard of living reflects the state's implementation of other humans' rights. The public officials of the countries with planned economies have formed a strategy of transformation, which is focused on conducting reforms aimed at macroeconomic stabilization and microeconomic restructuring.

Enough time has passed since the beginning of the restructuring of states with planned economies, which makes it possible to thoroughly analyze the economic indicators of countries, their level of development and ensuring the implementation of humans' economic rights.

\section{Literature Review}

Recognition of social-economic rights at the international level took place at the beginning of the XXth century. The improvement of the legal regulation of these rights at the international level occurred after the Second World War, which was characterized by the adoption of a number of international legal acts that enshrined social-economic rights, namely: The Universal Declaration of Human Rights (UDHR) was proclaimed by the United Nations General Assembly in Paris on December 10, 1948, International Covenant on Economic, Social and Cultural Rights (ICESCR) adopted and opened for signature and ratification and accession by General Assembly resolution 2200A (XXI) on December 16, 1966, International Convention on the Elimination of All Forms of Racial Discrimination adopted and opened for signature and ratification by General Assembly resolution 2106 (XX) on December 21, 1965, Convention on the Rights of the Child adopted and opened for signature, ratification and accession by General Assembly resolution 44/25 on November 20, 1989 (Ahmed and Bulmer, 2017).

International Covenant on Economic, Social and Cultural Rights adopted by United Nations General Assembly on December 16, 1966 establishes a list of the human's economic rights, namely: Article 1 - the right to self-determination; Article 6 - the right to work; Article 7 - the right to fair and favorable working conditions; Article 8 
- the right to form trade unions and strikes; Article 11 - the right to an adequate standard of living (including the right to housing and food) (United Nations Human Rights, n.d.). All countries in transition have signed the ICESCR, committing themselves to ensure the implementation and protection of economic and social cultural rights of people.

A transition economy or a post-communist economy is an economy that reflects the process of transforming a centrally planned (socialist) economy into a market economy (Gurkov, 2015). Transition economies make it possible for countries to choose policies that are more likely to create a progressive economy and society (CSQ, n.d.). Countries in transition include: Croatia, Hungary, Poland, Romania, Slovenia, the Czech Republic, Bulgaria, North Macedonia, Slovak Republic, Albania, Estonia, Lithuania, Latvia, Cambodia, Laos, Vietnam, China (International Monetary Fund, 2000).

The objectives of the transition period are as follows:

- privatization - the transition of state property to private ownership;

- denationalization - the establishment of public administration' boundaries of the economy, which involves the restriction of direct public administration;

- reform - the transformation of property relations into those that are inherent in a market economy;

- demonopolization - antitrust policy, creation of a competitive market and its protection;

- liberalization - deregulation of prices and control over most goods and services, freedom of trade;

- creation of innovative market infrastructure;

- macroeconomic stabilization;

- creation of a modern system of social protection (Fedorenko, 2015).

The feature of the transition economy involves the implementation of hoarding of citizens' incomes. Such practice comes around as a result of the unstable economy, social change, the creation of market institutions (Vitort, 2002).

According to point of view of Korolenko (2004), the first stage of the transition to a market economy is its liberalization. Weakening of labour remuneration by state administration was a prerequisite for the formation of the labor market, which has created a balance between supply and demand. The transition of the economy to a market economy has become a prerequisite for reforming the labor sphere, which has not been completed yet and is spontaneous in nature.

The transition period is defined as a process that involves the transition from a centrally planned economy to a market-oriented one. There is no single unique example of a country in transition, as all of them have different economic, 
geographical, cultural, general social contexts. The basic characteristics of the transition economy include privatization, liberalization, macroeconomic stabilization, legal and institutional reforms (Trivic and Petkovic, 2015).

Petrishina (2014) successfully notes that the process of transition economy requires scientific support, determination of directions of development and elaboration of its long-term strategy. The latter requires improving the sphere of private property; it should combine and effectively correlate state management of the economy, corporate governance and ensuring the functioning of institutional mechanisms of various forms of ownership.

Economic and social rights are enshrined in international law acts on human rights, namely the right to education, living standards, employment, health and social security. They should be guaranteed by states without discrimination. Increasing social-economic inequality and discrimination are the basic obstacles to the implementation of social and economic rights (The Equal Rights Trust, 2014).

Economic rights are "old" rights; they occupy a relatively high level in the hierarchy of rights of EU citizens. There are legal, administrative, linguistic and other reasons for non-exercise of these rights (De Vries and Pulice, 2018).

\section{Research Methodology}

The study of the implementation of economic rights in transition countries has been carried out using a method of comparison, which consists in comparing indicators of unemployment, minimum wage, ease of doing business and the level of corruption in highly developed economies and countries in transition.

The cause and effect link between the level of economy of transition countries and the implementation of humans' economic human rights has been established by applying the elementary theoretical method. The main causes of unfavorable conditions for the implementation of economic rights in transition states have been highlighted by applying the method of analysis.

In the academic paper, an analysis of the scientific literature from 1944 to 2020 has been carried out, where the transition economy, economic rights and the provision of individual economic rights of citizens of transitional states were investigated. The statistical data of individual states (Denmark, Japan, Iceland, the Czech Republic, Ukraine, Latvia) in the matter of the level of unemployment, the size of the minimum wage, the level of ease of doing business, the level of corruption, the size of GDP per capita have been analyzed. The reasons of lack of proper provision in the matter of economic rights' implementation by the states in transition have been established by applying the method of generalization and analogy. 
The academic paper has analyzed: Gross National Income per capita, Unemployment rate, Ease of Doing Business, Corruption Rank, the minimum wage:

- The World Bank - GDP (gross national income) per capita (current US\$) Denmark, Japan, Ukraine, Latvia, the Czech Republic, Iceland;

- Statista - Unemployment rate from 2010 to 2019;

- Trading Economics - Ease of Doing Business; Corruption Rank;

- Country economy - The minimum wage from 2010 to 2019.

\section{Empirical Findings}

The process of economic transformation involves the introduction of the following measures, namely: liberalization of international trade, formation of private enterprises, accompanied by privatization of state property, creation of appropriate business conditions, implementation of investment policy accompanied by direct investment, abolition of central planning, formation of the banking system, securities market, adoption of legislation in the sphere of private property (Gurkov, 2015).

The list of established social-economic rights differs between countries, which may range in the names of rights, the features of the geographical location of countries, the predominance of specific social groups. Economic rights may become more specific in less developed countries. There is a standard list of enshrined economic rights for all countries that are most vulnerable in transition, signed by the International Covenant on Economic, Social and Cultural Rights.

The implementation of economic rights directly depends on their provision by the state. Thus, the right to an adequate standard of living, the right to entrepreneurial activity, the right to private property depend on the economic development of the country and the guarantees of the minimum income that the state can provide. Over the last 20 years, countries in transition have not reached the level of highly developed countries. This is evidenced by their level of GDP per capita (Figure 1).

Figure 1. GNI (gross national income) per capita (current US\$) from 2010 to 2018

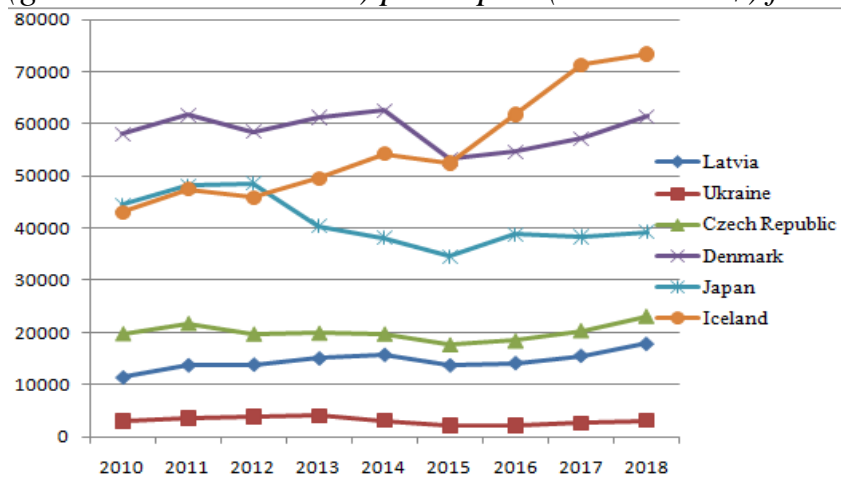

Source: The World Bank (2018). 
The countries with stable and developed economies, Japan, Iceland, and Denmark, the level of GDP per capita has not fallen below 34500 USD per capita for 8 years. The countries in transition, Latvia, Ukraine, the Czech Republic, the level of GDP per capita has not risen above 23100 USD for 8 years, and in Ukraine, in particular, the highest indicator of GDP per capita was 4029 USD in 2013.

The right to an adequate standard of living is directly dependent on the economic development of the state. Taking into consideration the fact that the countries in transition have not reached proper economic development, the ensuring of the implementation of the economic right specified can not be carried out. Such conclusion is made on the basis of the analysis of statistics on the minimum wage of Japan, Ukraine, Latvia, and the Czech Republic (Country Economy, 2020).

In Japan, the minimum wage for 9 years ranged from 1134,6 to 1506 USD, and in transition countries the minimum wage did not exceed 593 USD this wage was observed in the Czech Republic in 2019.

It is submitted that the economic development of the state directly affects the implementation of the right to an adequate standard of living. The level of the minimum wage in the transition countries is directly proportional to the level of economic development of the country.

One of the reasons for failure to ensure the implementation of the right to an adequate standard of living for citizens of countries in transition is the leveling of development and evaluation of human capital.

Human capital is a priority link in creating a state's stable developed economy. Such conclusion is based on the fact that human capital brings significant profits to the state. Thus, at the beginning of the XXIst century in the United States, human capital brought 95 trillion USD of national income, which is $77 \%$ of US national wealth; in Ukraine, human capital brought 3,5 trillion USD of national income, which is 55\% of Ukraine's national wealth (Valentey, 2003).

Reducing the volume and non-full use of human capital in transition countries to the full extent is one of the reasons for the economic lag behind developed countries. Here difficulties arise in implementation of the right to self-determination, the right to work and the right to an adequate standard of living. One of the reasons for this situation is the low income of the population, which makes it difficult for enterprises to invest in the development of human capital. Consequently, cause and effect link emerges between the economic development of the state, human capital and the implementation of economic rights, which are interdependent categories (Perepelytsya, 2005).

Countries in transition have experienced increasing unemployment threatening the implementation of the right to work. The reasons for unemployment were as follows: 
privatization of state property, the creation of private entrepreneurship, which tried to become more efficient by cutting jobs. The policy of communist countries centered around maximum employment, however, when private enterprises were formed, labor costs were reduced in order to increase their efficiency. In addition, the privatization of state property, denationalization led to a decrease in state enterprises, which entailed cutting jobs (Figure 2).

Figure 2. Unemployment rate from 2010 to 2019

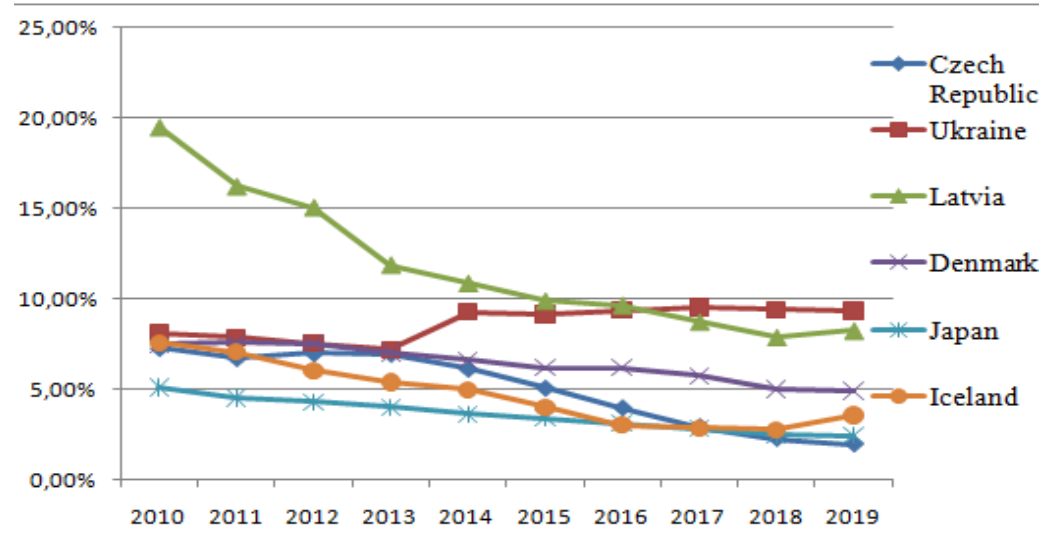

Source: Authors, Statista (2020a-f).

It has been established that a smaller percentage of the population is unemployed in economically developed countries (Japan 2,41\%, Iceland 3,55\%, Denmark 4,91\%) to compare with countries in transition (Ukraine 9,31\%, Latvia 8,22\%). The exception is the Czech Republic, which accounts for $2,41 \%$ of the unemployed population. Analysts attribute the following reasons for the decline in unemployment in the Czech Republic to an increase in industrial production, growth in the economy, increase in types of seasonal work (Petrenko, 2018).

The basis of a market economy centers around ensuring the implementation of the right to private property and its protection. The creation or expansion of property rights creates the conditions for long-term investments, the development of relations with suppliers and manufacturers. Significant is the fact that the right of private property makes it possible to create enterprises and increase production, which has a positive impact on economic development (Hartwell, 2015).

The development of entrepreneurship in the framework of the implementation of private property's right creates a course of economic development. Under the conditions of a transition economy, the functions of entrepreneurship include increasing employment through job creation, development of economic competition, diversification of goods and services in the market, removal of social tension, saturation of the market with goods and services, increasing consumers' demand (Tolmachova, 2000). 
It has been established that for 9 years, countries with a high level of economy in a sustained fashion, with a small deviation, have provided favorable conditions for entrepreneurship. Positive dynamics is observed in transition countries, for example, Ukraine from 152 rank rose to 64 place for 9 years. However, it occupies the worst position among the studied countries in transition. The reasons for this rating among other countries are the weak innovation support, small amount of investment, noncompetitiveness of national goods produced by small enterprises, reorientation of small business, which tends to trade, shadow economy of business entities (Tolmachova, 2000).

Property rights in countries in transition, despite the positive dynamics, remain at a low level. Such situation is caused by the unstable tax regime, corruption in the public sphere, arbitrary judicial system, and non-enforcement of compulsory decisions. The situation specified creates risks for investors who refuse to invest in business in transition economies, which has a negative impact on the economy itself (Taran, 2000).

Denmark is the least corrupt nation of 180 countries, according to the Corruption Perceptions Index as of 2019. Countries with a high level of GDP are referred to the countries with a low level of corruption, while countries in transition occupy a middle level among corrupted countries. The exception is Ukraine, which is a highly corrupted country compared to others. There is a direct link between the level of economic development of states and the level of corruption (Figure 3).

Figure 3. Corruption Rank (The Corruption Perceptions Index classifies countries and territories according to their perceptions of their corrupt public sector)

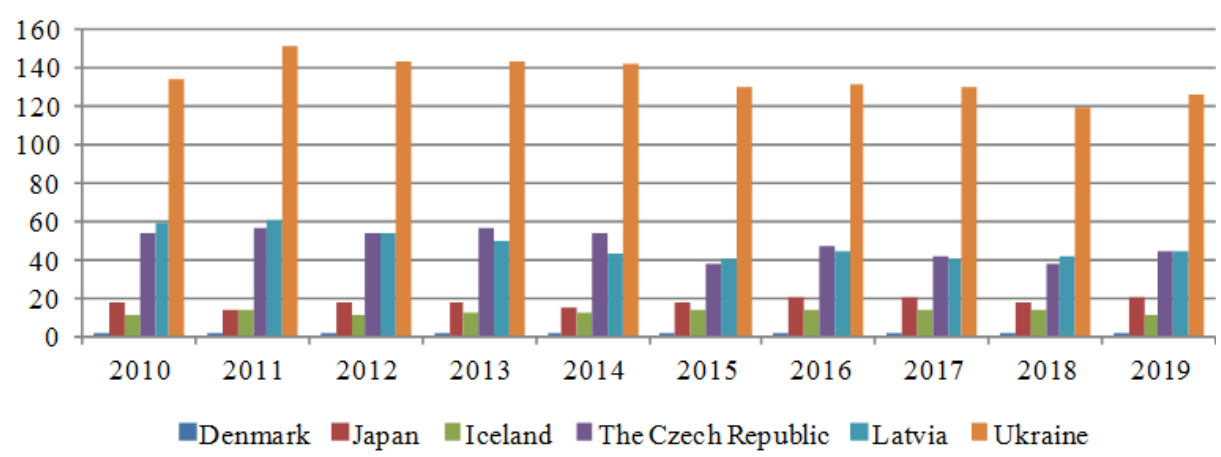

Source: Authors, Trading Economics (2020).

\section{Discussion and Conclusions}

Based on the research conducted, it has been established that the most vulnerable economic rights in transition countries are the right to private property, the right to work, and the right to an adequate standard of living. The implementation of economic rights is ensured by the state. However, the depressed period for the 
economy of transition countries has a negative impact on the implementation of economic rights by their citizens. A cause and effect link has been proved between the level of economic development, the level of unemployment, the attraction of human capital, the minimum wage, the ease of doing business, the level of corruption and the implementation of economic rights. The categories specified are interdependent and variable to change the level of each of the categories.

The reasons for the low level of ensuring the implementation of economic rights in transition countries have been identified by the insufficient level of economic development, in comparison with highly developed countries, the lack of conditions to attract the investment needed by transition countries to modernize the private sector, the failure to use human capital to full extent and leveling of its development, the number of job cuts, the level of thr shadow economy of business entities' activities, the poor innovation support, and high level of corruption.

The ways to improve the conditions for the implementation of economic rights center around reforming the areas that affect the economic development of the state, creating favorable conditions for the functioning of entrepreneurship (improving the legal regulation of tax legislation, establishing the boundaries of public administration, providing loans on favorable terms), crackdown on corruption (increasing the weight of state bodies through qualified selection of personnel, checking for integrity, establishing favorable working conditions), investing public funds in human capital (development and proper evaluation), demonopolization, creating favorable conditions for the development of national production, attracting innovative technologies that will make it possible to produce competitive goods at the international level. Thus, increasing the number of jobs (reducing unemployment), increase in wages by revising the value of goods produced and increasing its share in GDP, withdrawal of wages from the shadow economy.

The development of a long-term strategy for economic growth and stabilization by using these paths in transition countries will create favorable conditions for the implementation of humans' economic rights.

In the context of the research on the implementation of economic rights in countries in transition, it has been established that countries in transition have not achieved high economic development, as evidenced by their level of GDP per capita. Such situation creates obstacles to the implementation of economic rights, and states cannot ensure humans' economic rights to the full extent. The countries in transition are characterized by stable, average, and high unemployment, corruption, and low minimum wage. The positive dynamics in these countries is observed in the creation of favorable conditions for doing business.

The cause and effect links between a number of interdependent and interconnected institutions, responsible for economic growth and ensuring the implementation of economic rights, have been studied. It has been established that states in transition 
have common features in ensuring the implementation of economic rights, however, there are exceptions, for example, the Czech Republic, where a positive practice in overcoming unemployment is observed.

It has been proved that a well-coordinated state policy in raising the economic level, the absence of corruption and political stability will create the proper conditions for the development of the private sector, and ensure the implementation of economic rights.

\section{References:}

Ahmed, D., Bulmer, E. 2017. Social and Economic Rights. $2^{\text {nd }}$ edition. International Institute for Democracy and Electoral Assistance, Stockholm, Sweden.

Country Economy. 2020. NMW - National Minimum Wage. Available at: https://countryeconomy.com/national-minimum-wage.

CSQ. n.d. Transition Economics - The Science of Sustainable Economics and Government Policy. Available at: https://csq1.org/transition-economics/.

De Vries, S., Pulice, E, 2018. Economic rights of EU citizens within a multilevel context: Monograph Chapter. In: S. Seubert, M. Hoogenboom, T. Knijn, S. de Vries \& F. van Waarden (Eds.), Moving Beyond Barriers. Prospects for EU Citizenship. Interdisciplinary Perspectives on EU Citizenship series. Edward Elgar Publishing Ltd., Cheltenham, UK, 137-157.

Fedorenko, V.H. 2015. Political Economy. Alerta, Kyiv, Ukraine.

Gurkov, I. 2015. Transition Economy. In: C.L. Cooper, M. Vodosek, D.N. Hartog \& J.M. McNett, (Eds.), Wiley Encyclopedia of Management. John Wiley \& Sons, Hoboken, NJ. https://doi.org/10.1002/9781118785317.weom060204.

Hartwell, C.A. 2015. Property Rights in Transition Countries. In: J. Hölscher and H. Tomann (Eds.), Palgrave Dictionary of Emerging Markets and Transition Economics. Springer, Cham, Switzerland, 170-189.

International Monetary Fund. 2000. Transition Economies: An IMF Perspective on Progress and Prospects.Available at: https://www.imf.org/external/np/exr/ib/2000/110300.htm.

Korolenko, A.V. 2004. Remuneration in the conditions of market transformation of the economy: essence, functions, directions of reforming. PhD dissertation abstract. V.N. Karazin Kharkiv National University, Kharkiv, Ukraine.

Perepelytsya, N.V. 2005. Human capital in a transformational economy: content and main directions of formation. PhD dissertation abstract. V.N. Karazin Kharkiv National University, Kharkiv, Ukraine.

Petrenko, A. 2018. The unemployment rate in the Czech Republic has reached a 21-year low. Available at: https://uagolos.com/riven-bezrobittia-v-chehiji-dosiag-21-richnogominimymy/.

Petrishina, N.V. 2014. Problems of transformation of the economy of Ukraine. The Bulletin of the M.P. Drragomanov NPU, Series 18: Economics and Law, 24, 31-38.

Statista. 2020a. Czech Republic: Unemployment rate from 1999 to 2019. Available at: https://www.statista.com/statistics/369864/unemployment-rate-czech-republic/.

Statista. 2020b. Denmark: Unemployment rate from 1999 to 2019. Available at: https://www.statista.com/statistics/318316/unemployment-rate-in-denmark/.

Statista. 2020c. Iceland: Unemployment rate from 2009 to 2021 . Available at: https://www.statista.com/statistics/398960/unemployment-rate-in-iceland/. 
Statista. 2020d. Japan: Unemployment rate from 1999 to 2019. Available at: https://www.statista.com/statistics/263700/unemployment-rate-in-japan/.

Statista. 2020e. Latvia: Unemployment rate from 1999 to 2019. Available at: https://www.statista.com/statistics/375253/unemployment-rate-in-latvia/.

Statista. 2020f. Ukraine: Unemployment rate from 1999 to 2019. Available at: https://www.statista.com/statistics/296132/ukraine-unemployment-rate/.

Taran, S. 2000. Property rights, Institutions and private sector development in transition countries. PhD disserataion abstract. National University "Kyiv-Mohyla Academy", Kyiv, Ukraine.

The Equal Rights Trust. 2014. Economic and Social Rights: A Litigator's Guide to Using Equality and Non-Discrimination Strategies to Advance Economic and Social Rights. Available at: https://www.equalrightstrust.org/ertdocumentbank/ESR_Guide.pdf.

The World Bank. 2018. GDP per capita (current US\$) - Denmark, Japan, Ukraine, Latvia, Czech Republic, Iceland. Available at: https://data. worldbank.org/indicator/NY.GDP.PCAP.CD?end=2018\&locations=DKJP-UA-LV-CZ-IS\&start=2010.

Tolmachova, H. 2000. Regulation of small business development in the transition economy of Ukraine. PhD dissertation abstract. Institute of Industrial Economics, National Academy of Sciences of Ukraine, Donetsk, Ukraine.

Trading Economics. 2020. Corruption Rank. Available at: https://tradingeconomics.com/ukraine/corruption-rank.

Trivic, J., Petkovic, S. 2015. Different Features of Transition Economies: Institutions Matter. In: L.P. Dana \& V. Ramadani (Eds.), Family Businesses in Transition Economies. Springer, Cham, Switzerland, 71-96.

United Nations Human Rights. n.d. International Covenant on Economic, Social and Cultural Rights (ICESCR). Available at: https://www.ohchr.org/EN/professionalinterest/pages/cescr.aspx.

Valentey, S.D. 2003. The development of society in the theory of social alternatives. Nauka, Moscow, Russia.

Vitort, T.V. 2002. Investment and economic growth: the relationship in transition economies. $\mathrm{PhD}$ dissertation abstract. V. N. Karazin Kharkiv National University, Kharkiv, Ukraine. 